\title{
Outbreak of enzootic ataxia in goats and sheep in the state of Bahia ${ }^{1}$
}

\author{
Thanielle N. Fontes², Jeferson S. Carvalho³, Múcio F.F. Mendonça², Soraya S. Farias ${ }^{3}$, \\ Clara Satsuki Mori ${ }^{6}$, Danielle N. Silva ${ }^{4}$, Karina M. Madureira ${ }^{5}$ (C) \\ and Tiago C. Peixoto ${ }^{5 *}$
}

\begin{abstract}
Fontes T.N., Carvalho J.S., Mendonça M.F.F., Farias S.S., Mori C.S., Silva D.N., Madureira K.M. \& Peixoto T.C. 2019. Outbreak of enzootic ataxia in goats and sheep in the state of Bahia. Pesquisa Veterinária Brasileira 39(12):961-969. Laboratório de Patologia Veterinária, Escola de Medicina Veterinária e Zootecnia, Universidade Federal da Bahia, Av. Adhemar de Barros 500, Salvador, BA 40170-110, Brazil. E-mail: tcpeixoto@ufba.br

The objective of this study was to describe for the first time the clinical-epidemiological, laboratory and pathological aspects of different forms of enzootic ataxia in goats and lambs in the state of Bahia, as well as to propose an emergency oral treatment with copper sulfate in an individualized way for neonates. Three outbreaks of enzootic ataxia were studied. The history, clinical signs and epidemiological data were obtained from the owners and checked during the visits. The first outbreak (FO) occurred in 2013 in a property located in the municipality of Itaberaba and affected a herd composed of 90 goats and 130 sheep. The second outbreak (SO) occurred in 2014 in the municipality of Santa Luz and affected a herd of 90 goats and 110 sheep. The third outbreak (TO) occurred in 2018, in a property located in the same municipality of the SO, being the herd constituted by 80 sheep. Samples of blood were collected from all goats and sheep treated for serum copper dosage. Nine animals (five goats and four sheep) that presented a more severe clinical picture and unfavorable prognosis were necropsied for diagnostic confirmation. During the necropsy of the FO, SO and TO animals, liver samples were collected for copper dosage as well as fragments of several organs for histopathology. At the site where the SO occurred, samples of soil and the main forages where the animals were kept were collected to determine copper, iron, molybdenum, sulfur and zinc contents. The clinical and histopathological findings in the three outbreaks studied were characteristic of enzootic ataxia. In the outbreaks studied, the frequency of enzootic ataxia was higher in goats (52) than in lambs (39). In the goats the mean values of serum copper $(0.05 \mathrm{mg} / \mathrm{kg})$ and hepatic $(2.48 \mathrm{mg} / \mathrm{kg})$ of the FO and SO were well below their respective reference values, 12 times lower than serum levels and eight times lower in relation to liver contents. On the other hand, TO sheep presented mean values of serum copper $(0.015 \mathrm{mg} / \mathrm{kg})$ reduced by 40 times. The levels of iron and sulfur were high in the fodder of the property where the SO occurred, already in the soil, iron levels were high and copper levels were reduced. The treatment tested in neonates and lambs with two doses of copper sulphate solution orally at a dose of $20 \mathrm{mg} / \mathrm{kg}$ for sheep and $35 \mathrm{mg} / \mathrm{kg}$ for goats during the first and second week of life was effective in prevention of enzootic ataxia in neonates and can be used for emergency control of the disease. The occurrence of enzootic ataxia (congenital and late form) in goats and sheep was first reported in Bahia. It is also worth noting that this disease caused by copper deficiency has caused great damage to the breeders of small ruminants, mainly due to the high mortality of the animals affected.
\end{abstract}

INDEX TERMS: Outbreak, enzootic ataxia, goats, sheep, Bahia, Brazil, copper, small ruminants, mineral deficiency, microelement.

\footnotetext{
${ }^{1}$ Received on June 7, 2019.

Accepted for publication on August 2, 2019.

Part of the first author's Master Thesis, financed by CAPES.

${ }^{2}$ Post-Graduate Program in Animal Science in the Tropics, Escola de Medicina Veterinária e Zootecnia (EMEVZ), Universidade Federal da Bahia (UFBA), Av. Adhemar de Barros 500, Salvador, BA 40170-110, Brazil.

${ }^{3}$ Self-employed Veterinarian.

${ }^{4}$ Doctoral student of the Post-Graduate Program in Animal Science in the
}

Tropics, Universidade Federal da Bahia (UFBA), Av. Adhemar de Barros 500, Salvador, BA 40170-110.

${ }^{5}$ Departamento de Anatomia, Patologia e Clínicas Veterinárias, Escola de Medicina Veterinária e Zootecnia (EMEVZ), Universidade Federal da Bahia (UFBA), Av. Adhemar de Barros 500, Salvador, BA 40170-110. *Corresponding author: tcpeixoto@ufba.br

${ }^{6}$ Departamento de Clínica Médica, Universidade de São Paulo (USP), Av. Dr. Éneas de Carvalho Aguiar 155, Setor Azul, SP 05403-6300, Brazil. 
RESUMO.- [Surto de ataxia enzoótica em caprinos e ovinos no estado da Bahia.] Objetivou-se com esse estudo descrever pela primeira vez os aspectos clínico-epidemiológicos, laboratoriais e patológicos de diferentes formas de ataxia enzoótica em cabritos e borregos no estado da Bahia, bem como propor um tratamento oral emergencial com sulfato de cobre de forma individualizada para neonatos. Foram estudados três surtos de ataxia enzoótica. O histórico, sinais clínicos e dados epidemiológicos foram obtidos com os proprietários e verificados durantes as visitas técnicas. 0 primeiro surto (PS) ocorreu em 2013 em uma propriedade localizada no município de Itaberaba e acometeu um rebanho composto por 90 caprinos e 130 ovinos. 0 segundo surto (SS) aconteceu em 2014 no município de Santa Luz e afetou um rebanho formado por 90 caprinos e 110 ovinos. 0 terceiro surto (TS) ocorreu 2018, em uma propriedade localizada no mesmo município do SS, sendo o rebanho constituído por 80 ovinos. Amostras de sangue foram colhidas de todos os caprinos e ovinos atendidos, para dosagem de cobre sérico. Nove animais (cinco caprinos e quatro ovinos) que apresentavam quadro clínico mais grave e prognóstico desfavorável foram necropsiados para confirmação diagnóstica. Durante a necropsia dos animais do PS, SS e TS amostras de fígado foram coletadas para dosagem de cobre, bem como amostras de diversos órgãos para exame histopatológico. Na propriedade onde ocorreu o SS, foram coletadas amostras de solo e das principais forragens onde os animais eram mantidos, a fim de se determinar os teores de cobre, ferro, molibdênio, enxofre e zinco. Os achados clínicos e histopatológicos verificados nos três surtos estudados foram característicos de ataxia enzoótica. Nos surtos estudados, a frequência da ataxia enzoótica foi maior em cabritos (52) do que em cordeiros (39). Nos caprinos os valores médios de cobre sérico $(0,05 \mathrm{mg} / \mathrm{kg})$ e hepático $(2,48 \mathrm{mg} / \mathrm{kg})$ do PS e SS encontravam-se muito abaixo dos respectivos valores de referência, sendo 12 vezes menor em relação aos níveis séricos e oito vezes menor em relação aos teores hepáticos. Já os ovinos do TS apresentavam valores médios de cobre sérico $(0,015 \mathrm{mg} / \mathrm{kg})$ reduzidos cerca de 40 vezes. Os teores de ferro e enxofre encontravam-se elevados nas forragens da propriedade onde ocorreu o SS, já no solo, os níveis de ferro apresentavam-se elevados e os de cobre reduzidos. 0 tratamento testado nos cabritos e borregos neonatos, com duas administrações individualizadas com solução de sulfato de cobre, por via oral, na dose de $20 \mathrm{mg} / \mathrm{kg}$ para ovinos e $35 \mathrm{mg} / \mathrm{kg}$ para caprinos, na primeira e segunda semana de vida, foi eficaz na prevenção da ataxia enzoótica nos neonatos e pode ser utilizado para controle emergencial da doença. Comprovou-se pela primeira vez na Bahia a ocorrência da ataxia enzoótica (forma congênita e tardia) em caprinos e ovinos. Ressalta-se ainda que, esta doença causada por deficiência de cobre, tem cursado com grandes prejuízos aos criadores de pequenos ruminantes, sobretudo, devido à alta mortalidade dos animais acometidos.

TERMOS DE INDEXAÇÃO: Surto, ataxia enzoótica, caprinos, ovinos, estado da Bahia, cobre, pequenos ruminantes, deficiência mineral, microelemento.

\section{INTRODUCTION}

Enzootic ataxia may be due to primary (simple) copper deficiency in the diet, or secondary (Tokarnia et al. 2010), (conditioned) due to the presence of antagonists in the diet.
Antagonists interfere with the use or absorption of copper by the animal (Tokarnia et al. 1966, Riet-Correa et al. 2001, Suttle 2010), such as molybdenum, sulfur, zinc and iron (Gould \& Kendall 2011). Copper's interactions with other elements can make difficult to establish dietary requirements of this microelement for the animals of a herd, which emphasizes the importance of evaluating the epidemiological characteristics of each property, in an attempt to determine the predisposing regional factors for the occurrence of cupric deficiency.

The disease manifests itself in two forms: congenital and late. The congenital form presents a primary lesion localized in the cerebral white matter that occurs in the first days after birth. This can lead to stillbirths or weak animals, unable to stay in season and tetraparesis, who usually die during the first week of life. In the late form, the primary lesion occurs in the motor tract of the spinal cord and brainstem (Riet-Correa et al. 2001, Santos et al. 2006, Zatta \& Frank 2007), one to two weeks after birth and manifests itself with ataxia and paresis of the pelvic limbs (Lewis et al. 1974).

In Brazil, the first outbreaks of enzootic ataxia were identified in Piauí from 1954 to 1958 by Tokarnia et al. (1966) in 12 lambs up to six months old. The disease, until then of unclear etiology, was known as "escancho". After evaluating clinical, necroscopic, histopathological histories and liver copper levels, the authors concluded that the disease is associated with copper deficiency, similar to known enzootic ataxia, in countries such as Australia, England and New Zealand. Later, Santos et al. (2006) reported an outbreak of late enzootic ataxia in 46 goats and 35 lambs in the wild region of Pernambuco state (PE), which was attributed to a large amount of iron in forage and soil. Subsequently, other studies were performed in PE using a serum and hepatic copper dosages, one in the Araripina region. A primary marginal copper deficiency was found in 141 goats and 141 sheep (Marques et al. 2011) and another in backcountry (Sertão region) of the São Francisco river valley (Silva Junior et al. 2015). However, in this last study, the dosages performed in 80 goats and 80 sheep did not show a copper deficiency. In 2008, in the municipality of Mossoró (RN), there was an outbreak of late enzootic ataxia affecting five lambs in which high liver levels were observed iron (Sousa et al. 2012). Recently, Silva et al. (2014) reported four outbreaks of late enzootic ataxia and one congenital outbreak in goats in the semiarid region of Paraíba state. Recent studies in Bahia evaluated mineral levels in 80 goats and 80 sheep raised in the municipalities of Casa Nova and Juazeiro. However, the mean serum and hepatic values of copper and zinc found did not indicate mineral deficiency, although serum iron levels were found high (Silva et al. 2016).

No descriptions of copper deficiency outbreaks were found in ruminants in the state of Bahia. Thus, this study aimed to describe, for the first time, outbreaks of copper deficiency in goats and sheep in the municipalities of Itaberaba and Santa Luz/BA.

\section{MATERIALS AND METHODS}

First outbreak. The first outbreak (FO) occurred in February 2013 , in a property located in the municipality of Itaberaba $\left(12^{\circ} 31^{\prime} 40^{\prime \prime} \mathrm{S}, 40^{\circ} 18^{\prime} 25^{\prime \prime} \mathrm{W}\right)$, Chapada Diamantina region, in two herds, one consisting of 90 crossbred goats Boer and another by 130 Dorper crossbred sheep. The herds were reared on an extensive pasture-based diet, predominantly grass, supplemented with corn and 
protein mineral salt for cattle. The water supplied to the animals in drinking fountains was piped from the river. According to the owner only young animals ( 45 days to eight months) were affected by the disease caused by sex. The animals showed cambial gait, weakness and chronic incoordination of pelvic limbs with progression to decubitus, followed by death. However, an evolution of the clinical picture was individual for each animal, starting between the first and second month of life. There were no previous histories of this disease on the farm and in the region. Inspection of the installations revealed that the iron pipes supplying running water to the drinking fountains were highly oxidized. On this occasion, one male, crossbred, castrated (eight months old) goat (goat1-F0), and one sheep (sheep1-F0) presented clinical manifestations of the disease and were referred to CDP-UFBA for clinical follow-up and treatment. The sheep1-F0 showed clinical improvement, with significant gait and balance recovery, and after 21 days was discharged. The goat1-FO remained hospitalized for 40 days, did not respond to the treatment instituted, and, due to the worsening of the clinical condition (progressing to permanent decubitus) and unfavorable prognosis, the owner opted for euthanasia and necropsy.

Second outbreak. The second outbreak (SO) occurred in August 2014, in the municipality of Santa Luz, northeastern Bahia, at a farm with a herd of 90 goats and another herd of 110 sheep of no defined breed. The animals were bred extensively with feed based on native Caatinga pasture and supplemented with goat mineral salt and pond water. According to history, four years ago, the disease affected goats and, to a lesser extent, sheep, and there was an increase in the number of cases each year. The disease evolved chronically and progressed with incoordination of the pelvic limbs, which manifested shortly after birth or between one and two-month-old goats and worsened over the weeks, with more frequent falls and difficulty walking (Fig.1). During the visit, 14 live goats (of the 34 initially affected) presented clinical signs. Among these, we selected three castrated male goats aged between three and five months (goat1-SO, goat2-SO, and goat3-SO) for physical evaluation, as they presented more pronounced clinical signs. Due to the unfavorable prognosis, the owner opted for euthanasia and necropsy for a diagnostic conclusion. We visited the farm again in June 2018. During the inspection of the herd, a recently calved goat (goat4-SO) exhibited clinical signs characteristic of the congenital form of enzootic ataxia. The newborn goat presented weakness, inability to get up and stay stationary (Fig.2), paresthesia of the pelvic limbs, as well as tachycardia, lethargy, wheezing and inability to ingest colostrum. Goat4-SO was followed for about six hours, and due to worsening of the clinical picture with unfavorable prognosis, it was euthanized in extremis and necropsied.

Third outbreak. The third outbreak (TO) occurred in June 2018 , in a property located in the same municipality of the SO (Santa Luz, $11^{\circ} 15^{\prime} 21^{\prime \prime} \mathrm{S} / 39^{\circ} 22^{\prime} 30^{\prime \prime} \mathrm{W}$ ), with the herd consisting of 80 non-breed sheep. The herd was bred extensively on native pasture and received vitamin supplementation with mineral salt for sheep and water from the pond. According to the breeder, the disease had affected sheep for seven months, was chronic and affected only young animals up to 90 days old, and usually had a fatal outcome. Adult animals showed no clinical changes, and there was no sexual predilection. The animals presented incoordination of the pelvic limbs (Fig.3), weakness, staggering gait, frequent falls when moving, with progression to decubitus and death. At the time of the visit, six sheep presented clinical signs of the disease, we selected the four most affected animals for physical evaluation (sheep1-T0, sheep2-T0, sheep3-T0, and sheep4-T0), three males and one female,

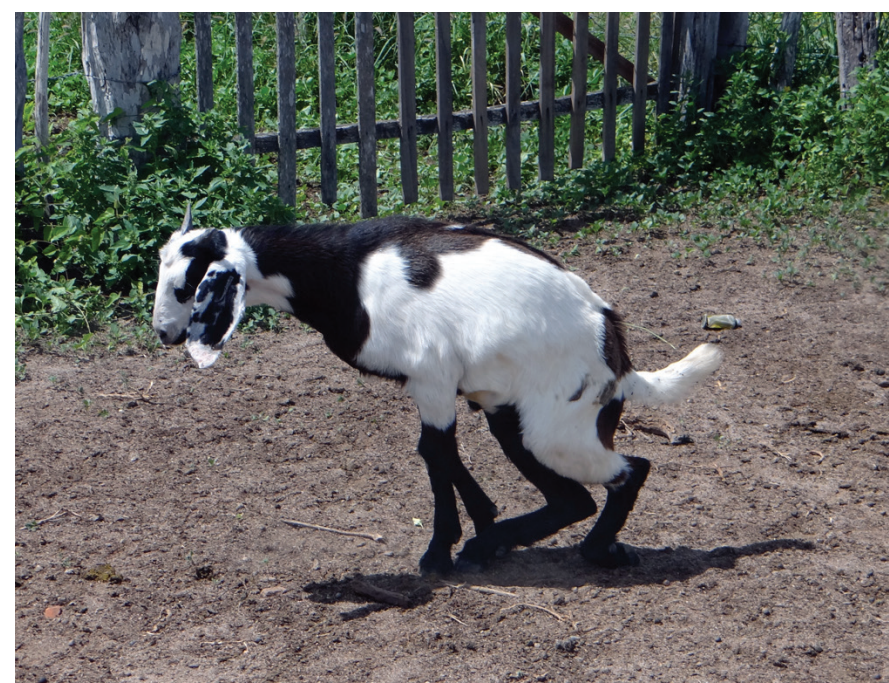

Fig.1 Incoordination of the pelvic limbs and difficulty in locomotion. Late enzootic ataxia, Goat 2 of the second outbreak.

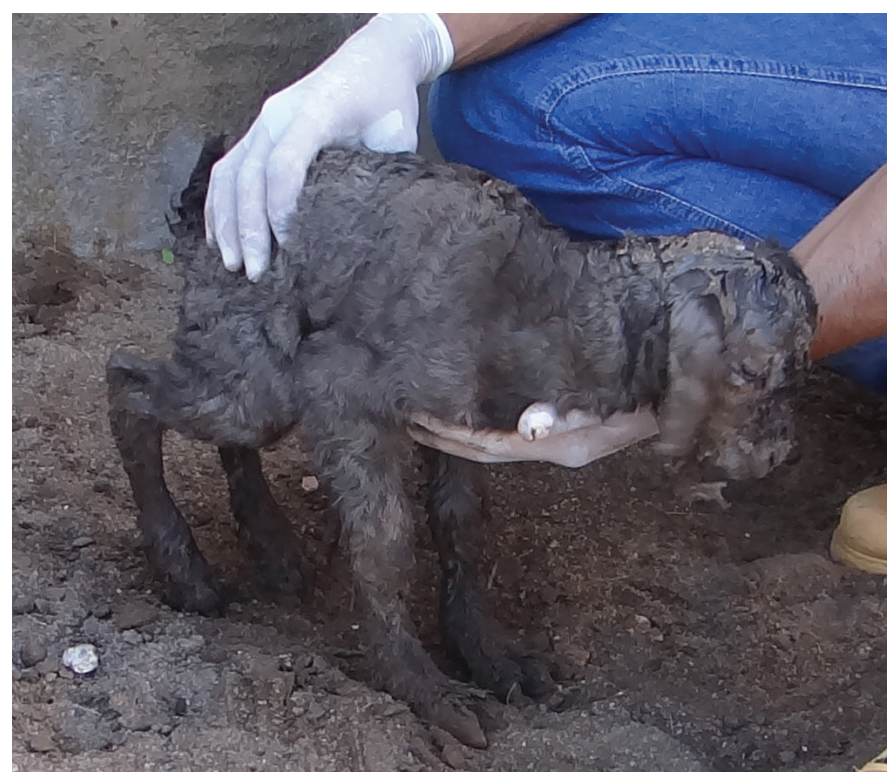

Fig.2. Newborn goat with weakness and inability to stay in season. Congenital enzootic ataxia, Goat 4 of the second outbreak.

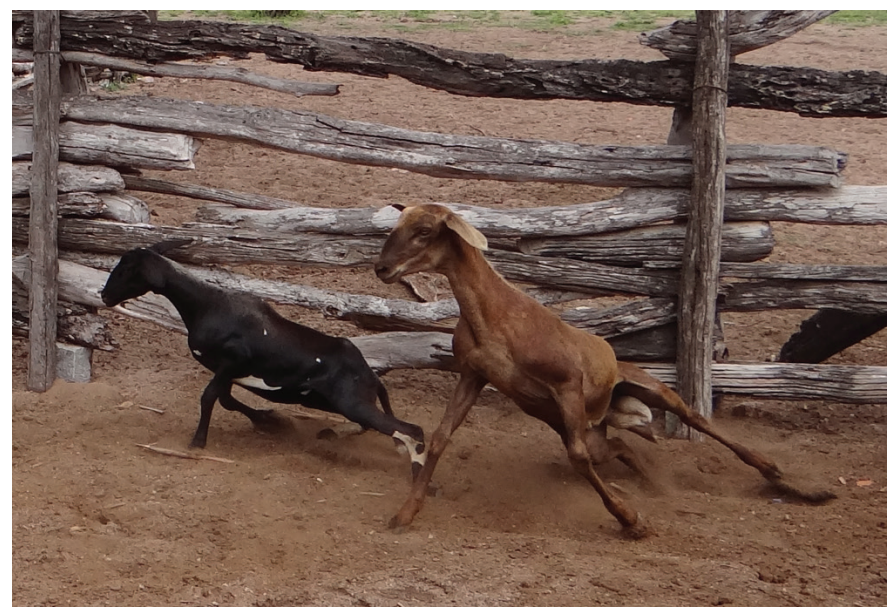

Fig.3. Incoordination of the pelvic limbs' moments before the fall. Late enzootic ataxia, Sheep 2 and 3 of the third outbreak. 
aged three to eight months. These four sheep were euthanized by the owner's choice and then necropsied for diagnostic elucidation.

Biochemical exam. We collected blood samples from the evaluated animals (goat1-FO, goat1-SO, goat2-SO, goat3-SO, goat4-SO, sheep1-T0, sheep2 -T, sheep3-T0 and sheep4-T0) by puncture of the jugular veins using $5 \mathrm{~mL}$ syringes and needles (Descarpack ${ }^{\circledR}$ ). Serums for biochemical analysis were obtained after clot retraction, centrifuged at a speed of 1200rpm for ten minutes, and then stored in a polyethylene microtube (Eppendorf), protected from light and stored at $-20{ }^{\circ} \mathrm{C}$ (Lopes et al. 2007). The samples collected from goat1-FO, goat1-SO, goat2-SO and goat3-SO were sent to the Faculty of Veterinary Medicine and Animal Science of the University of São Paulo (USP) and the animals goat4-S0, sheep1-TO, sheep2-T0, sheep3-T0 and sheep4-T0 were sent to Axys Analyzes Laboratory (Porto Alegre, Rio Grande do Sul) for serum levels of $\mathrm{Cu}$.

Necropsy. A total of nine animals (five goats and four sheep), together with the three outbreaks, were necropsied for the diagnostic conclusion. During necropsy, fragments of organs from the abdominal and thoracic cavity, brain, spinal cord, skin, and femoral biceps muscle were collected. This material was fixed in 10\% phosphatebuffered formalin and sent to the Veterinary Pathology Laboratory of the Federal University of Bahia (LPV-UFBA).

Histopathology. After fixation, these materials were cleaved, routinely processed for histopathology, and stained with hematoxylin-eosin (HE). For better evidence of demyelination, some spinal cord fragments of the nine animals and goat4-SO brain embedded in paraffin were referred to the Veterinary Pathology Sector (SPV) of the Federal University Rio Grande do Sul(UFRGS) to perform the method Klüver-Barrera, using Luxol Fast Blue staining (Klüver \& Barrera 1953).

Hepatic copper dosage. Liver fragments were collected from all nine autopsied animals using clean stainless steel razors, stored in $50 \mathrm{~mL}$ polypropylene tubes and frozen at $-20^{\circ} \mathrm{C}$. The material referring to goats goat1-FO and goat1-S0, goat2-SO and goat3-S0, was sent to the Faculty of Veterinary Medicine and Animal Science of the University of São Paulo (USP) for hepatic Cu dosage. The samples were placed in trays and in an automated LIOTOP ${ }^{\circledR}$ device (model L101), then ground and pistil crushed (Pinheiro et al. 2011). Mineral dosing was performed according to the technique previously described by Nomura et al. (2005), using the technique of induced plasma optical emission spectrometry (ICP-OES) in the VARIAN Vista-MPX simultaneous axial CCD equipment in an automatic sampling system.

Soil and plant analysis. We collected soil samples and the central pasture plants and forages from two paddocks of the property where the SO occurred, where the animals were kept. These samples were sent to the Agricultural and Environmental Analysis Laboratory in Linhares (ES), for the determination of $\mathrm{Cu}, \mathrm{Fe}, \mathrm{Mo}, \mathrm{S}$, and $\mathrm{Zn}$ contents. We also collected samples of the following plants: malva (Malva sylvestris), native grass, signal grass (Urochloa mosambicensis), buffel grass (Cenchrus ciliaris L.), guinea grass (Panicum maximum cv. Green Panic) and "icó" (Capparis yco). Soil samples were collected from ten different pasture points of each paddock analyzed. After homogenization and quartering, two $150 \mathrm{mg}$ samples were obtained, which were sent for analysis, according to recommendations from Embrapa (1997).

Treatment. Prophylactic treatment in goats and neonatal loans, with two individual administrations with oral copper sulfate solution, $35 \mathrm{mg} / \mathrm{kg}$ dose for goats, and $20 \mathrm{mg} / \mathrm{kg}$ for sheep, in the first and second week of life.

Statistical analysis. All data obtained from the study were tabulated, collected, ordered, and analyzed using descriptive statistics in order to obtain possible correlations between the various clinical factors, soil, water, and pastures.

\section{RESULTS AND DISCUSSION}

The diagnosis of the three outbreaks of enzootic ataxia in small ruminants occurred in two municipalities of Bahia, based on epidemiological data, history, clinical signs, and necroscopic examination, confirmed by histopathological evaluation and serum and hepatic copper dosages. Additionally, the copper deficiency was also confirmed by the analysis of mineral contents in plants and soil from the property where the SO occurred.

\section{Clinical aspects}

The main clinical signs found in the five goats and four sheep of the three outbreaks studied are shown in Table 1. Similar findings were described in goats (Cordy \& Knight 1978, Banton et al. 1990, Riet-Correa et al. 2001, Dinev et al. 2005, Santos et al. 2006, Sousa et al. 2012, Silva et al. 2014) and sheep (Tokarnia et al. 1966, Riet-Correa et al. 2001,

Table 1. Clinical signs presented by goats and sheep of the three outbreaks of enzootic ataxia diagnosed in Bahia

\begin{tabular}{|c|c|c|c|c|c|c|c|c|c|}
\hline & $\begin{array}{c}\text { Goat } 1 \\
\text { FO }\end{array}$ & $\begin{array}{c}\text { Goat } 1 \\
\text { SO }\end{array}$ & $\begin{array}{c}\text { Goat } 2 \\
\text { SO }\end{array}$ & $\begin{array}{c}\text { Goat } 3 \\
\text { SO }\end{array}$ & $\begin{array}{c}\text { Goat } 4 \\
\text { SO }\end{array}$ & $\begin{array}{c}\text { Sheep } 1 \\
\text { T0 }\end{array}$ & $\begin{array}{c}\text { Sheep } 2 \\
\text { T0 }\end{array}$ & $\begin{array}{c}\text { Sheep } 3 \\
\text { T0 }\end{array}$ & $\begin{array}{c}\text { Sheep } 4 \\
\text { TO }\end{array}$ \\
\hline Sacral loin hyperesthesia & $\mathrm{x}$ & $\mathrm{x}$ & $\mathrm{x}$ & $\mathrm{x}$ & $\mathrm{x}$ & $\mathrm{x}$ & $\mathrm{x}$ & $\mathrm{x}$ & $\mathrm{x}$ \\
\hline Ataxia & $\mathrm{x}$ & $\mathrm{x}$ & $\mathrm{x}$ & $\mathrm{x}$ & $\mathrm{x}$ & $\mathrm{x}$ & $\mathrm{x}$ & $\mathrm{x}$ & $\mathrm{x}$ \\
\hline Motor incoordination & $\mathrm{x}$ & $\mathrm{x}$ & $\mathrm{x}$ & $\mathrm{x}$ & $\mathrm{x}$ & $\mathrm{x}$ & $\mathrm{x}$ & $\mathrm{x}$ & $\mathrm{x}$ \\
\hline Muscle tremors & $\mathrm{x}$ & $\mathrm{x}$ & $\mathrm{x}$ & $\mathrm{x}$ & $\mathrm{x}$ & $\mathrm{x}$ & $\mathrm{x}$ & $\mathrm{x}$ & $\mathrm{x}$ \\
\hline Frequent falls & $\mathrm{x}$ & $\mathrm{x}$ & $\mathrm{x}$ & $\mathrm{x}$ & $\mathrm{x}$ & $\mathrm{x}$ & $\mathrm{x}$ & $\mathrm{x}$ & $\mathrm{x}$ \\
\hline Abnormal postures & $\mathrm{x}$ & $\mathrm{x}$ & $\mathrm{x}$ & $\mathrm{x}$ & $\mathrm{x}$ & $\mathrm{x}$ & $\mathrm{x}$ & $\mathrm{x}$ & $\mathrm{x}$ \\
\hline Achromotrichia & $\mathrm{x}$ & $\mathrm{x}$ & $\mathrm{x}$ & $\mathrm{x}$ & $\mathrm{x}$ & $\mathrm{x}$ & $\mathrm{x}$ & $\mathrm{x}$ & $\mathrm{x}$ \\
\hline Bad nutritional status & - & $\mathrm{x}$ & $\mathrm{x}$ & $\mathrm{x}$ & - & - & - & - & - \\
\hline Dry cough & $\mathrm{x}$ & - & - & - & - & $\mathrm{x}$ & $\mathrm{x}$ & $\mathrm{x}$ & $\mathrm{x}$ \\
\hline Dyspnea & $\mathrm{x}$ & - & - & - & - & - & - & - & - \\
\hline Dry sterols & $\mathrm{x}$ & - & - & - & - & - & - & - & - \\
\hline Sacral loin hyperesthesia & $\mathrm{x}$ & - & - & - & - & - & - & - & - \\
\hline
\end{tabular}


Santos et al. 2006, Sousa et al. 2012, Oliveira Filho 2016) with cupric disability. Additionally, one goat (goat1-F0) presented respiratory changes such as dry cough, dyspnea, and bilateral diffuse dry rales secondary to prolonged decubitus.

Periocular achromotrichia identified in the SO goats is related to melanin deficiency since copper participates in the synthesis of the enzyme polyphenol oxidase, which transforms tyrosine into melanin and dopamine, and leads to more severe depigmentation of the hair around the eyes in animals with cupric deficiency. In these cases, brown, red, or black fur may be clarified and reddish or whitish, which can be seen in the SO goats (Quiroz-Rocha \& Bouda 2001). Nutritional deficiency in the SO animals may be related to food scarcity, since the outbreak occurred during the dry season, coupled with the difficulty of locomotion and, consequently, the search for food (Tokarnia et al. 1966). The respiratory alterations found (goat1-F0) are probably due to the animal's low immunological condition and prolonged decubitus, also described by Santos et al. (2006), who reported cough and catarrhal nasal discharge, as well as conjunctivitis and contagious ecthyma.

When evaluating the occurrence of enzootic ataxia in all herds studied in the Northeast, there was a higher occurrence of the disease in goats (52) than in lambs (39). The higher number of affected goats may be explained by the higher serum and hepatic copper concentrations in this species when compared to sheep (Riet-Correa et al. 2001). This finding indicates that the nutritional requirements of goats are higher than in sheep, making them more susceptible (Riet-Correa et al. 2001). However, such differences were found in a study conducted in small ruminants raised in Pernambuco, where serum and hepatic copper concentrations were found higher in goats $(11.37 \pm 2.57 \mu \mathrm{mol} / \mathrm{L}$ and $152.46 \pm 79.58 \mathrm{ppm})$ than in sheep $(9.85 \pm 2.71 \mu \mathrm{mol} / \mathrm{L}$ and $158.45 \pm 83.05 \mathrm{ppm})$ considered healthy and sent for slaughter (Marques et al. 2011). Santos et al. (2006), emphasize that there is no difference in serum and copper contents $(11.7 \mu \mathrm{mol} / \mathrm{L} \pm 1.6)$, but highlighted the importance of new studies to confirm their exposure. On the other hand, Silva et al. (2016) found differences in the serum concentration $(12.2 \pm 0.4 \mu \mathrm{mol} / \mathrm{L}$ sheep and $13.8 \pm 0.3 \mu \mathrm{mol} / \mathrm{L}$ goats $)$ and hepatic (238 $\pm 14 \mu \mathrm{mol} / \mathrm{L}$ sheep and $220 \pm 13 \mu \mathrm{mol} / \mathrm{L}$ goats) averages of $\mathrm{Cu}$ in goats and sheep in the state of Bahia.

In the FO, the frequency indexes of enzootic ataxia were $36.67 \%$ in goats $(33 / 90)$ and $7.69 \%$ in sheep (10/130); For the SO, the frequency was of $38.89 \%$ (34/90) in goats and in the TO there was $37.5 \%(30 / 80)$ in sheep. These indexes were similar to those described by Santos et al. (2006), in the wild region of Pernambuco State, which found a prevalence of $46.3 \%$ and $24.2 \%$ in goats $(25 / 54)$ and lambs (15/62), respectively. Regarding mortality, mortality rates were $35.6 \%(32 / 90)$ for goats and $7.69 \%(10 / 130)$ for sheep. In the S0, mortality was $68.6 \%$ (24/35) in goats, and in the T0, it was $45 \%(36 / 80)$. On the other hand, Sousa et al. (2012) observed mortality rates around 75\% in a property composed of 56 sheep in the municipality of Mossoró/RN. Santos et al. (2006) observed mortality of $44.4 \%$ for goats and $22.6 \%$ for sheep in a property located in Surubim/PE. Several factors can influence these rates, such as time of year, animal susceptibility, the concentration of copper antagonists in soil and pasture, mineralization performed and outbreak duration without technical intervention (Peixoto et al. 2005,
Marques et al. 2011), which could justify the differences between the obtained indexes.

Regarding the animals' age in the outbreaks studied, we found that the disease affected newborns to four months old animals. Signs of enzootic ataxia may vary in animals of different ages due to the fact that goats and lambs born from mothers with less severe copper deficiency have normal myelination at birth and develop demyelination in the postnatal period (Radostitis et al. 2007). Also, the fetal myelination process begins in late pregnancy and first occurs in the brain, extending centrifugally to the spinal cord when it is completed only 30 days after birth (Gambling et al. 2011).

Thus, considering the myelination period and the age of the animals affected in the outbreaks studied, we determined that the late form of the disease is common, corroborating the outbreaks reported in other studies (Santos et al. 2006, Sousa et al. 2012, Silva et al. 2014). However, on the property of the SO, the birth of an animal (goat4-SO) with neurological signs was observed, compatible with the congenital presentation of the disease, which was confirmed by serum copper dosage $(0.011 \mathrm{mg} / \mathrm{kg})$, as well as lesions macro and microscopic features.

In the case of sudden death, the diagnosis of enzootic ataxia can be made by assessing the liver or serum levels of the mineral; however, the assessment of deaths on the property is especially important to rule out poisoning by toxic plants (Riet-Correa et al. 2001). It is noteworthy that, in the present study, a differential diagnosis was made with plant poisoning with neurological changes and sudden death, cerebellar hypoplasia, meningitis, intestinal parasitism (Radostitis et al. 2007), soft goat syndrome (Riet-Correa et al. 2004), caprine arthritis encephalitis (Riet-Correa et al. 2001), polioencephalomalacia (Lima et al. 2005) and oropharyngeal and neurological lesions associated with the use of metering guns (Sant'Ana et al. 2007). For such differentiation, we performed pasture inspections, clinical and epidemiological data evaluation, macroscopic and histopathological examinations, as well as copper dosages.

\section{Biochemical}

The results of the biochemical measurements of copper are shown in Table 2 . In goats, the mean serum $(0.05 \mathrm{mg} / \mathrm{kg})$ and hepatic $(2.48 \mathrm{mg} / \mathrm{kg}$ ) copper values of the FO and SO were well below their respective values $(0.6-1.5 \mathrm{mg} / \mathrm{kg}$ and $<20 \mathrm{mg} / \mathrm{kg})$

Table 2. Blood and liver copper levels in goats and sheep from enzootic ataxia outbreaks in the state of Bahia

\begin{tabular}{lcc}
\hline \multicolumn{1}{c}{ Animal } & Serum $(\mathrm{mg} / \mathrm{kg})$ & Hepatic $(\mathrm{mg} / \mathrm{kg})$ \\
\hline goat1-F0 & 0.045 & 1.911 \\
goat1-S0 & 0.056 & 0.083 \\
goat2-S0 & 0.083 & 4.440 \\
goat3-S0 & 0.052 & 3.489 \\
goat4-S0 & 0.011 & - \\
sheep1-T0 & 0.012 & - \\
sheep2-T0 & 0.016 & - \\
sheep3-T0 & 0.013 & - \\
sheep4-T0 & 0.018 & - \\
Reference values & $0.6-1.5$ & $<20$
\end{tabular}

$\mathrm{FO}=$ first outbreak, $\mathrm{SO}=$ second outbreak, $\mathrm{TO}=$ third outbreak. 
(Underwood 1981, Radostitis et al. 2007), 12 times lower than serum levels, and eight times lower than liver levels. The TO sheep had mean serum copper values $(0.015 \mathrm{mg} / \mathrm{kg})$ reduced about 40 times. These mean values were lower than those found by Marques et al. (2011) in Bahia in serum and hepatic dosages of sheep $(9.58 \pm 2.52 \mu \mathrm{mol} / \mathrm{L}-158.45 \pm 83.05 \mathrm{mg} / \mathrm{kg})$ and goats $(11.55 \pm 2.68 \mu \mathrm{mol} / \mathrm{L}-152.46 \pm 79.58 \mathrm{mg} / \mathrm{kg})$ healthy for slaughter.

\section{Macroscopic and microscopic findings}

No significant macroscopic lesions were found in any of the goats and sheep that presented the late form of enzootic ataxia in the outbreaks studied. Goat4-SO, which developed the congenital form of the disease, showed marked brain lesions in the white matter, especially in the parietal and temporal lobes characterized by bilateral symmetric hydranencephaly (Fig.4) without white matter, similar to that described by Radostitis et al. (2007). Additionally, in some cases, nonspecific macroscopic changes and/or secondary to prolonged decubitus were observed, such as areas of pulmonary consolidation in the ventral cranial portions and purulent exudate in the bronchial lumen (goat1-F0), mild pulmonary edema, mild pulmonary emphysema and focal atelectasis (goat1-SO, goat2-SO, goat3-SO), small bowel mucosa hyperemia with brownish mucosal content (goat1-F0), mild parasitic abomasitis, mild splenomegaly, mild to moderate regional lymphadenomegaly and mild mesenteric, moderate multifocal crusted chronic dermatitis (goat1-SO, goat2-SO, and goat3-SO). Histopathological evaluation showed the spinal cord, mild to moderate demyelination/degeneration of myelin in brain white matter (goat4-SO), and cervical and lumbar parts, mainly in separate funicles (Fig.5) and multi-stage chromatolysis (goat1- F0, goat1-SO, goat2-SO, and goat3-SO). Also, a special Luxol Fast Blue stain on goat1-FO, goat1-SO, goat2-SO, goat3-SO, ov1-T0, sheep2-T0, sheep3-T0, and sheep4-T0 evidenced the cervical, thoracic, and lumbar parts of the spinal cord multifocal areas of white matter hypomyelination (Fig.6) in the dorsal, ventral lateral region, and ventral medial fissure, in addition to multistage chromatolysis and hypomyelination of goat4-SO cerebral white matter.

The histological lesions found were characteristic of enzootic ataxia caused by copper deficiency, showing intense vacuolization of white matter, axonal spheroids associated with axonal swelling due to demyelination (Dinev et al. 2005). There was an intense inflammatory infiltrate composed of macrophages, neutrophils, and lymphocytes within the alveoli, bronchi, and bronchioles (bronchopneumonia secondary to prolonged decubitus), as well as moderate hepatocyte vacuolization, predominantly periportal, small foci of necrosis, hemorrhage, and accumulation of debris, cells in the liver of goat1-FO. No histological lesions were observed in the gray matter, which corroborates the fact that the affected animals did not have a lack of appetite, fever, and thirst, since in the gray matter, mainly, the hypothalamus is responsible for regulating such functions (Zachary 2013). Recently Silva et al. (2014) used as a complementary diagnostic method radiographic evaluations in goats, showing irregular patterns of radiolucency of long bones, resulting from the failure of endochondral ossification, which causes growth retardation, decrease in weight gain and gear changes.

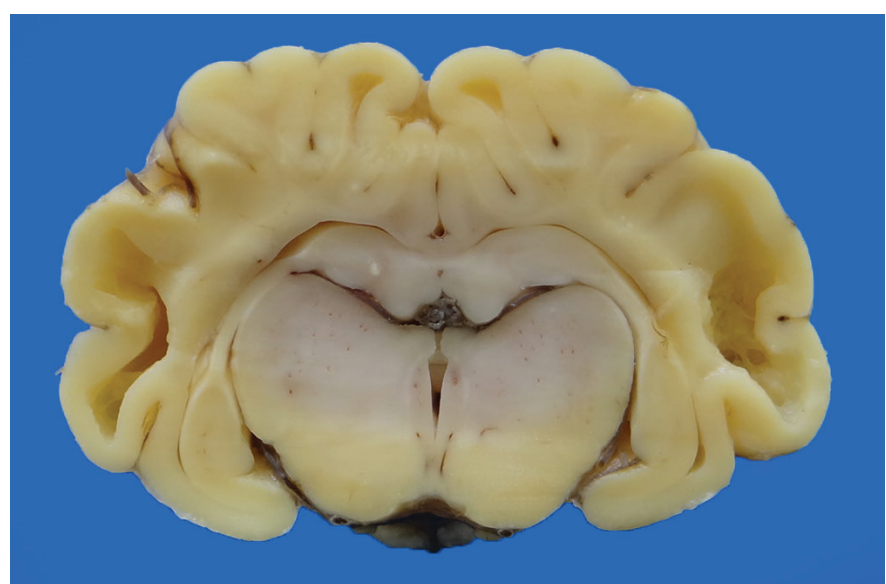

Fig.4. Brain cross-section showing bilateral symmetrical hydranencephaly. Congenital enzootic ataxia, parietal and temporal lobes, newborn goat (goat4-SO).

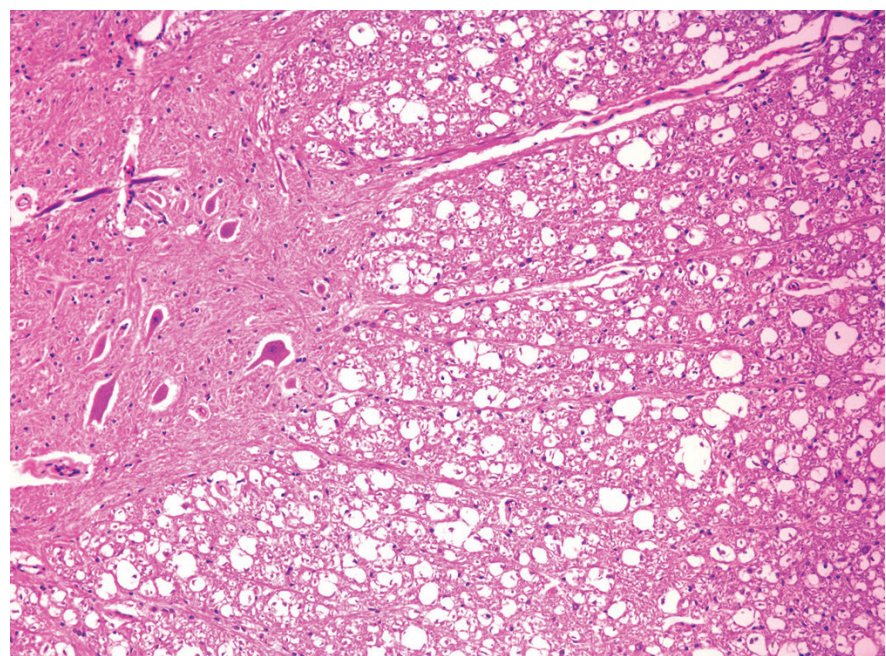

Fig.5. Marked multifocal hypomyelination of the white matter of the spinal cord. Late enzootic ataxia, Goat 2 of the second outbreak. HE, obj.10x.

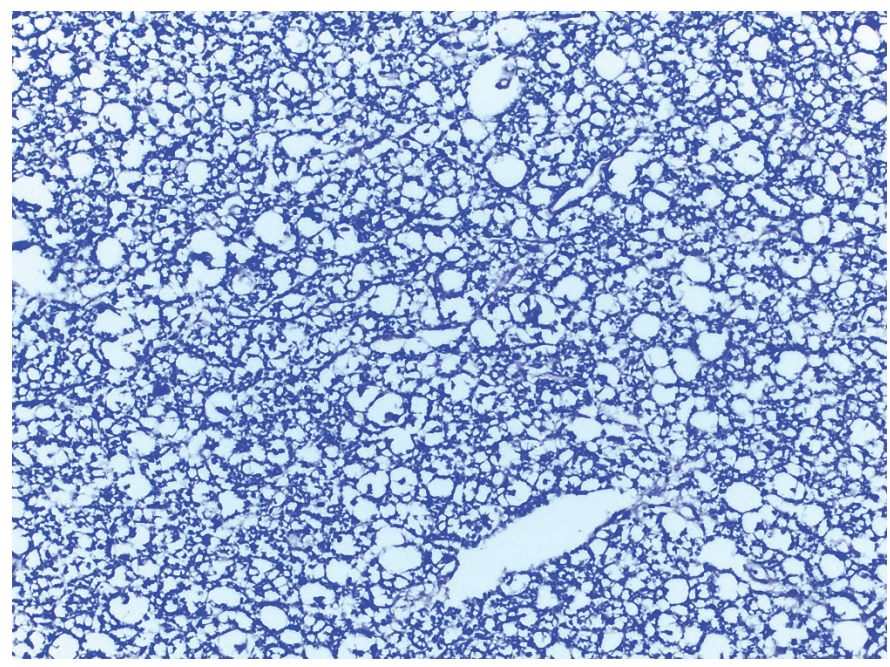

Fig.6. Marked diffuse hypomyelination of the white matter of the spinal cord. Congenital enzootic ataxia, newborn goat (goat4-SO). Luxol Fast Blue, obj.20x. 


\section{Soil and pasture analysis}

In farms where the FO and SO occurred, it could be determined that enzootic ataxia resulted from secondary (conditioned) copper deficiency. In the FO, although it was not possible to evaluate the mineral levels in the soil and pastures to confirm the triggering factor of deficiency, it was found that the iron pipe used to direct the water to the drinkers had very high oxidation, which strongly suggested high iron content in drinking water. In the SO, we prove that iron antagonism in the intestinal absorption of copper was the cause of the deficiency, considering the high levels of iron in the evaluated plants and the adequate levels of copper. Iron levels in the soil were also very high and copper levels low. The $\mathrm{Cu}, \mathrm{Fe}, \mathrm{Mo}, \mathrm{S}$, and $\mathrm{Zn}$ contents found in the pasture plant and soil samples used by the SO herd are shown in Table 3 and 4, respectively. The levels of copper required in the pastures (suitable for diet) are species-specific. In sheep, the appropriate copper value is $5 \mathrm{ppm}$, while goats require twice as high levels (10ppm). Levels of 3-5ppm are marginal and may cause clinical or subclinical deficiency. Secondary deficiency can occur in pastures with copper levels above $5 \mathrm{ppm}$, but with 3-10ppm molybdenum levels. In pastures with molybdenum levels below 3ppm and adequate copper levels, there is no risk of copper deficiency (Riet-Correa et al. 2001).

\section{Treatment}

Due to the suspicion of enzootic ataxia, goat1-FO and sheep1-FO were treated with oral copper sulfate solution at a dose of $35 \mathrm{mg} / \mathrm{kg}$ in a single dose and a $10 \mathrm{~mL} / \mathrm{vo}$ SID poly vitamin tonic (Poten Fort B12 ${ }^{\circledR}$ ), during all days of hospitalization. Sheep1-F0 showed clinical improvement and was discharged 21 days after the start of treatment. Goat1-FO remained hospitalized for 40 days, and although receiving the same treatment, no clinical improvement was obtained. We evaluated the efficacy of emergency prophylactic administration of an individually administered oral copper sulfate solution in animals from the herd of all three farms where outbreaks occurred (FO, SO, and TO). The first dose was administered shortly after birth and the second dose repeated after one week. This treatment was adapted from the few data found in other studies with goats and sheep (Radostitis et al.
2007, Pugh \& Baird 2012), given the scarcity of studies on the treatment of copper deficiency in these species. The evaluated treatment proved to be active and prevented the occurrence of new cases of late enzootic ataxia in all three properties. According to the farmers, after the beginning of prophylactic treatment, the disease only occurred when the newborn animals were mistakenly not treated prophylactically. No citations of prophylactic treatments of this nature were found in the literature. Such treatment also avoids the intoxication of sheep as they should not consume mineral mixtures with more than $0.4 \%-0.8 \%$ copper sulfate (Riet-Correa et al. 2004). However, for proper prophylaxis, soil correction/fertilization and supplementation of pregnant females is recommended to prevent the occurrence of the congenital form of the disease (Tokarnia et al. 1971, Peixoto et al. 2005).

We found significant direct and indirect economic losses on the visited properties due to the high mortality rates of the animals affected by enzootic ataxia. These facts were responsible for the dissatisfaction of the owners who claimed to be about to give up their creations and move to large cities if the problem was not solved. It is noteworthy that misconceptions about the real cause of the disease persist in the field and result in unnecessary treatments and the wrong combat of plants considered toxic and the perpetuation of the disease. Curiously, in the SO, the owner claimed that the producers in the region believed that the disease was genetically transmitted and had a hip bone malformation; while in the TO, the owner attributed the disease to plant poisoning. The CDP-UFBA extension work is essential for the dissemination of knowledge and technologies to small breeders of the state of Bahia (Santos et al. 2016), aiming at the consolidation of goat farming in the Brazilian semiarid, an activity that has an essential economic and socio-cultural role for the generation of income for small farmers, livestock production for subsistence and the establishment of man in the field.

\section{CONCLUSIONS}

The results obtained in this study confirmed for the first time the occurrence of enzootic ataxia (congenital and late form) in goats and sheep in the state of Bahia. This disease

Table 3. Copper, iron, manganese, sulfur and zinc contents in $\mathrm{mg} / \mathrm{kg}$ in the samples of plants collected from the pasture of the farm where the second outbreak occurred (Santa Luz/BA)

\begin{tabular}{crrrrrrrr}
\hline Micro minerals & Malva & Native grass & $\begin{array}{c}\text { Signal grass } \\
\text { (urucloa) }\end{array}$ & Buffel grass & Gripan grass & $\begin{array}{c}\text { "Icó” } \\
\text { (Capparis yco) }\end{array}$ & $\begin{array}{c}\text { Reference } \\
\text { values }\end{array}$ \\
\hline $\mathrm{Cu}$ & 5.0 & 5.0 & 5.0 & 5.0 & 4.0 & 5.0 & 4.8 & $4.0-14.0$ \\
$\mathrm{Fe}$ & 158.0 & 209.0 & 140.0 & 143.0 & 136.0 & 250.0 & 172.6 \\
$\mathrm{Mn}$ & 0.8 & 0.8 & 1.6 & 0.8 & 0.8 & 0.8 & $100.0-150.0$ & 0.9 \\
$\mathrm{~S}$ & 10.5 & 5.6 & 1.6 & 1.2 & 2.3 & 6.7 & 4.6 & $1.0-3.0$ \\
$\mathrm{Zn}$ & 25.0 & 18.0 & 18.0 & 20.0 & 45.0 & 19.0 & 24.1
\end{tabular}

Table 4. Copper, iron and sulfur contents in $\mathrm{mg} / \mathrm{dm}^{3}$ in the soil samples of the paddocks of the farm where the second outbreak occurred (Santa Luz/BA)

\begin{tabular}{ccccc}
\hline Micro minerals & Paddock 1 & Paddock 2 & Average & Reference values \\
\hline $\mathrm{Cu}$ & 0.30 & 0.20 & 0.25 & $0.60-1.5$ \\
$\mathrm{Fe}$ & 87.0 & 71.0 & 79.0 & $21.0-31.0$ \\
$\mathrm{~S}$ & 6.0 & 4.0 & 5.0 & $5.0-10.0$
\end{tabular}


caused by copper deficiency has been causing significant damage to small ruminant breeders, mainly due to the disease's high mortality.

Enzootic ataxia occurred in the studied farms due to secondary (conditioned) copper deficiency triggered by iron antagonist action. Oral prophylactic treatment with copper sulfate solution for newborn goats was effective in preventing the late form of enzootic ataxia in properties where outbreaks occurred and can be used as an emergency method for outbreak control.

Acknowledgements.- This study was partly financed by the "Coordenação de Aperfeiçoamento de Pessoal de Nível Superior" (CAPES), Brazil, Finance Code 001. The authors would like to thank Professor Dr. David Driemeier (UFGRS) by assisting with the Luxol Fast Blue staining.

Conflict of interest statement.- The authors have no competing interests.

\section{REFERÊNCIAS}

Banton M.I., Lozano-Alarcon F., Nicholson S.S., Jowett P.L., Fletcher J. \& Olcott B.M. 1990. Enzootic ataxia in Louisiana goat kids. J. Vet. Diagn. Invest. 2(1):70-73. <http://dx.doi.org/10.1177/104063879000200114> $<$ PMid:2090272>

Cordy D.R. \& Knight H.D. 1978. California goats with a disease resembling enzootica ataxia or sawayback. Vet. Pathol. 15(2):179-185. <http://dx.doi. org/10.1177/030098587801500204> <PMid:566481>

Dinev I., Petkov P., Todorov R., Kanakov D., Binev R. \& Petkova P. 2005. Clinical and morphologic studies of neonatal enzootic ataxia in the goat kids. Trakia J. Sci. 3:65-69.

Embrapa 1997. Manual de Métodos de Análise de Solo. $2^{\mathrm{a}}$ ed. Centro Nacional de Pesquisa de Solos, Rio de Janeiro, p.212.

Gambling L., Kennedy C. \& Mcardle H.J. 2011. Iron and copper in fetal development. Semin. Cell. Dev. Biol. 22(6):637-644. <http://dx.doi. org/10.1016/j.semcdb.2011.08.011><PMid:21893209>

Gould L. \& Kendall N.R. 2011. Role of the rumen in copper and thiomolybdate absorption. Nut. Res. Rev. 24(2):176-182. <http://dx.doi.org/10.1017/ S0954422411000059><PMid:22296933>

Klüver H. \& Barrera E. 1953. A method for the combined staining of cells and fibers in the nervous system. J. Neuropathol. Exp. Neurol. 12(4):400403. <http://dx.doi.org/10.1097/00005072-195312040-00008> $<$ PMid:13097193>

Lewis G., Terlecki S. \& Parker B.N.S. 1974. Observations on the pathogenesis of delayed swayback. Vet. Record 95(14):313-316.<http://dx.doi.org/10.1136/ vr.95.14.313><PMid:4450391>

Lima E.F., Riet-Correa F., Tabosa I.M., Dantas A.F.M., Medeiros J.M. \& Sucupira Júnior G. 2005. Poliencefalomalacia em caprinos e ovinos na região semiárida do Nordeste do Brasil. Pesq. Vet. Bras. 25(1):9-14. <http:// dx.doi.org/10.1590/S0100-736X2005000100003>

Lopes S.T.A., Biondo A.W. \& Santos A.P. 2007. Manual de Patologia Clínica Veterinária. 3aㅡ ed. Universidade Federal de Santa Maria, Centro de Ciências Rurais, Santa Maria, p.117.

Marques A.V.S., Soares P.C., Riet-Correa F., Mota I.O., Silva T.L.A., Borba Neto A.V., Soares F.A.P. \& Alencar S.P. 2011. Teores séricos e hepáticos de cobre, ferro, molibdênio e zinco em ovinos e caprinos no estado de Pernambuco. Pesq. Vet. Bras. 31(5):398-406. <http://dx.doi.org/10.1590/S0100736X2011000500006>

Nomura C.S., Silva S.S., Nogueira A.R.A. \& Oliveira P.V. 2005. Bovine liver sample preparation and micro-homogeneity study for $\mathrm{Cu}$ and $\mathrm{Zn}$ determination by solid sampling electrothermal atomic absorption spectrometry. Spectrochimica Acta Part B 60(5):673-680. <http://dx.doi.org/10.1016/j. sab.2005.02.021>

Oliveira Filho E.F. 2016. Aspectos nutricionais em cordeiros: surto de ataxia em cordeiros e resposta metabólica de cordeiros recebendo dietas com diferentes níveis de glicerina bruta. Master's Thesis, Universidade Federal Rural de Pernambuco, Recife. 81p.

Peixoto P.V., Malafaia P., Barbosa J.D. \& Tokarnia C.H. 2005. Princípios da suplementação mineral em ruminantes. Pesq. Vet. Bras. 25(3):195-200. <http://dx.doi.org/10.1590/S0100-736X2005000300011>

Pinheiro C.P., Bomjardim H.A., Andrade S.J.T., Faial K.C.F., Oliveira C.M.C. \& Barbosa J.D. 2011. Níveis de fósforo, cobre, cobalto e zinco em bubalinos (Bubalus bubalis) na Ilha de Marajó, Estado do Pará. Pesq. Vet. Bras. 31(3):193-198. <http://dx.doi.org/10.1590/S0100-736X2011000300002>

Pugh D.G. \& Baird A.N. 2012. Sheep and Goat Medicine. Elsevier, St Louis. 621p.

Quiroz-Rocha G.F. \& Bouda J.2001. Fisiopatologia de las deficiencias de cobre en rumiantes y su diagnostico. Vet. México 32:289-296.

Radostitis O.M., Gay C.C., Blood D.C. \& Hinchcliff K.W. 2007. Clínica Veterinária: um tratado de doenças dos bovinos, ovinos, suínos, caprinos e equinos. 9a ed. Guanabara Koogan, Rio de Janeiro, 1707p.

Riet-Correa F., Schild A.L., Mendez M.C. \& Lemos R.A.A. 2001. Doenças de Ruminantes e Equinos. Vol.2 2 2 ed. Varela Editora e Livraria, São Paulo. 578p.

Riet-Correa F., Tabosa I.M., Vasconcelos J.S. \& Medeiros J.M. 2004. Síndrome do cabrito mole ("Floppy Kid"). Pesq. Vet. Bras. 24(2):111-113. <http:// dx.doi.org/10.1590/S0100-736X2004000200011>

Sant'Ana F.J.F., Garcia E.C., Rabelo R.E., Costa Y.L., Schild A.L. \& Riet-Correa F. 2007. Lesões orofaríngeas e neurológicas em ovinos associadas ao uso de pistolas dosificadoras. Pesq. Vet. Bras. 27(7):282-286. <http://dx.doi. org/10.1590/S0100-736X2007000700005>

Santos M.M., Souza C.C.A., Menezes R.V., Figueredo L.J.C., Costa J.N., Madureira K.M., Cunha-Fernandes V. \& Peixoto T.C. 2016. Intoxicações por plantas em bovinos diagnosticadas pelo Centro de Desenvolvimento da Pecuária da Universidade Federal da Bahia, no período de 1985 a 2015. Pesq. Vet. Bras. 36(Suppl.2):187-189. (Resumo)

Santos N.V.M., Sarkis J.E.S., Guerra J.L., Maiorka P.C., Hortelani M.A., Silva F.F. \& Ortolani E.L. 2006. Avaliação epidemiológica, clínica, anatomopatológica e etiológica de surtos de ataxia em cabritos e cordeiros. Ciência Rural 36(4):1207-1213. <http://dx.doi.org/10.1590/S0103-84782006000400025>

Silva Junior S.S., Antonelli A.C., Soares G.W.N., Gomes I.M.M. \& Rocha Filho J.F. 2015. Determinação de cobre e outros minerais em caprinos e ovinos criados no sertão do vale do rio São Francisco, Pernambuco. Pesq. Vet. Bras. 35(9):767-774. <http://dx.doi.org/10.1590/S0100-736X2015000900001>

Silva T., Aguiar G., Carvalho F., Simões S., Miranda Neto E., Dantas A., Soares P. \& Riet-Correa F. 2014. Surtos de deficiência de cobre em ruminantes na região semiárida da Paraíba, Brasil. Semina, Ciênc. Agrárias 35:1955-1960.

Silva W.R., Gomes I.M.M., Rocha Filho J.F., Mori C.S., Michima L.E.S., Ortolani E.L. \& Antonelli A.C. 2016. Níveis séricos e hepáticos de cobre, zinco, ferro e molibdênio em ovinos e caprinos criados no semiárido da Bahia. Arq. Bras. Med. Vet. Zootec. 68(1):155-163. <http://dx.doi.org/10.1590/16784162-8450>

Sousa I.K., Hamad Minervino A.H., Sousa Rdos.S., Chaves D.F., Soares H.S., Barros Ide.O., de Araújo C.A., Júnior R.A. \& Ortolani E.L. 2012. Copper deficiency in sheep with high liver iron accumulation. Vet. Med. Inter. 2012:1-4.<http://dx.doi.org/10.1155/2012/207950><PMid:23320253>

Suttle N.F. 2010. Copper, p.255-305. In: Underwood E.J. (Ed), Mineral Nutrition of Livestock. 4th ed. MPG Books Group, Oxforshire. <http:// dx.doi.org/10.1079/9781845934729.0255> 
Tokarnia C.H., Dobereiner J., Canella C.F.C. \& Guimarães J.A. 1966. Ataxia enzootica em cordeiros na costa do Piauí. Pesq. Agropec. Bras. 1:375-382.

Tokarnia C.H., Guimarães J.A., Canella C.F.C. \& Döbereiner J. 1971. Deficiências de cobre e cobalto em bovinos e ovinos em algumas regiões do Brasil. Pesq. Agropec. Bras. 6:616-677.

Tokarnia C.H., Peixoto P.V., Barbosa J.D., Brito M.F. \& Döbereiner J. 2010. Deficiências Minerais em Animais de Produção. Helianthus, Rio de Janeiro, p.313-321.
Underwood E.J. 1981. Mineral Nutrition of Livestock. 2nd ed. MPG Books Group, Oxforshire, p.283-342.

Zachary J.F. 2013. Sistema nervoso, p.1054. In: McGavin M.D. \& Zachary J.F. (Eds), Bases da Patologia em Veterinária. 5a ed. Elsevier Brasil, Rio de Janeiro.

Zatta P. \& Frank A. 2007. Copper deficiency and neurological disorders in man and animals. Brain Res. Rev. 54(1):19-33. <http://dx.doi.org/10.1016/j. brainresrev.2006.10.001><PMid:17270275> 